\title{
Ahıska Kimliğinin Göç Sürecinde İnşası: Amerika'ya Göç Eden Ahıska Türkleri
}

\author{
Tuğça Poyraz** \\ Abdurrahim Güler ${ }^{* * *}$
}

Öz

Çalışmada 2005 ile 2007 yılları arasında Amerika Birleşik Devletleri'nin Florida Eyaleti' nin Jacksonville şehrine göç eden Ahıska Türklerinin kimliklerini oluşturan unsurlar, göç süreci içerisinde ele alınmıştır. Araştırmanın amacı, Ahıska Türklerinin Amerika’ya göç etme nedenlerinin, yaşadıkları sorunların ve göç sürecinin Ahıska kimliği üzerindeki yansımalarının ortaya konulmasıdır. Araştırmanın verileri, 2016 yılının Ocak-Mart ayları süresince Jacksonville'de yaşayan Ahıska Türklerinden elde edilmiştir. Ahıska Türklerinin sosyal gerçekliklerini onların bakış açılarından anlamak önemli olduğu için çalışmada 9 Ahıska Türkü ile derinlemesine görüşme yapılmış ve gündelik hayatlarını geçirdikleri mekânlarda katılımlı gözlem gerçekleştirilmiştir. Araştırmada Ahıska Türklerinin ABD’ye göç etmeden önce maruz kaldıkları ayrımcılık, en önemli sorun olarak ortaya çıkmıştır. Bunun yanı sıra Ahıska Türklerinin ABD’ye zorunlu olarak ve akrabalarıla birlikte göç ettikleri ve göç ettikten sonra da Ahıska kimliğinin temel unsurlarını korudukları gözlenmiştir. Ahıska Türklerinin kimliğini belirleyen temel unsurlar ise Türklük, Türkçe ve Müslümanlık olarak saptanmıştır.

\section{Anahtar Kelimeler}

Ahıska Türkü, göç, zorunlu göç, zincirleme göç, etnik kimlik, kültürel kimlik, dinsel kimlik.

\footnotetext{
* Geliş Tarihi: 03 Şubat 2018 - Kabul Tarihi: 12 Temmuz 2018

Bu makaleyi şu şekilde kaynak gösterebilirsiniz:

Poyraz, Tuğça ve Abdurrahim Güler (2019). "Ahıska Kimliğinin Göç Sürecinde İnşası: Amerika’ya Göç Eden Ahıska Türkleri”. bilig - Türk Dünyası Sosyal Bilimler Dergisi 91: 187-216.

" Doç. Dr., Hacettepe Üniversitesi, Edebiyat Fakültesi, Sosyoloji Bölümü - Ankara/Türkiye ORCID ID: https://orcid.org/0000-0003-3717-4728 tpoyraz@hacettepe.edu.tr

${ }^{* * *}$ Dr. Öğr. Üyesi, Ağrı İbrahim Çeçen Üniversitesi, Fen Edebiyat Fakültesi, Sosyoloji Bölümü - Ağrı/Türkiye ORCID ID: https://orcid.org/0000-0002-0317-8221 aguler@agri.edu.tr
} 


\section{Giriş}

Ahıska bölgesi terimi, Türkiye’nin kuzeydoğu, Ermenistan'ın kuzeybatı sınırında yer alan ve Gürcistan'ın güneybatısında Samtshe-Cavahetya bölgesinde bulunan Ahıska, Adigön, Aspinza, Ahılkelek ve Bogdanovka ile bu ilçelere bağlı 200'ün üzerinde köyden oluşan bölgeyi ifade etmektedir (Hasanoğlu 2015:76). Ahıska ya da Mesket Türkleri tanımları etnik değil, coğrafi bir adlandırma olup, Ahıska bölgesi ve Türkleri Anadolu Türklüğünün tabii devamıdır. Bu bölgedeki Türk varlığı eski tarihlere dayanmakta olup, 11. ve 12. yüzyıllarda bölge tamamen Türkleşmiştir. 16. yüzyılın sonuna doğru bölge, Osmanlı Devleti’ne katılmıştır (Demiray 2012: 77). 1828 yılına kadar Osmanlı Devleti sınırları içerisinde yaşayan Ahıska Türkleri, 1828-29 Osmanlı-Rus Savaşı sonunda Ahıska’nın Ruslara terk edilmesinden sonra Çarlık Rusyası ve Sovyetler Birliği’nin izlediği zorunlu göç ve sürgün politikalarıyla vatanlarından göç ettirilmişlerdir. Sovyetler Birliği içindeki çeşitli ülkelerde sürgün hayatı yaşayan Ahıska Türkleri, anavatanları olan Ahıska’ya bir daha dönememişlerdir (Yılmaz ve Mustafa 2014: 2).

II. Dünya Savaşı'nın başlamasıyla Ahıska bölgesinden 40.000 kadar Ahıskalı erkek Alman cephesine sevk edilmiş, Ahıskalı kadınlar, çocuklar ve yaşlılar ise demiryolu yapımında çalıştırılmıştır. 1944 yılının Kasım ayının 14’ünü 15'ine bağlayan gece ise Stalin'in emriyle Ahıska Türkleri trenlerle sürgün edilmiş (Buntürk 2015:88-89), yapımında çalıştıkları demiryolu birçoğuna mezar olmuştur. 1944 yılında gerçekleşen sürgünde yaklaşık olarak 90.000120.000 kişilik Ahıska Türkü topraklarından sürülüp, genellikle Orta Asya’ya ve özellikle de Özbekistan’a yerleştirilmiştir (Kurt 2015: 199). Ahıska Türklerinin sürgün edilmesinin nedeni, jeopolitik hesaplar ve Türkiye sınırına yakınlıktan kaynaklı endişeler ile bölgenin Türk ve Müslüman karakterinin değiştirilmek istenmesidir (Kolukırık 2011: 168).

1989 yılının Nisan ayında Özbekistan'da başlayan bir pazar kavgası, provokasyonların da etkisiyle günden güne büyümüştür. Fergana Olayları olarak bilinen kargaşada masum insanların canına kıyılmış, yüzlerce ev, hatta köyler yakılıp yıkılmış, iş yerleri ve otomobillere zarar verilmiştir. Bu olaylar sonucunda Ahıska Türkleri, burayı terk ederek Rusya’nın iç kesimlerine, Azerbaycan, Kazakistan, Kırgızistan ve Türkmenistan’a göç etmek zorunda kalmışlardır (Kurt ve Açıkgöz 2017: 109). 
Fergana olaylarından sonra Rusya'nın ortalarına yerleştirilen binlerce Ahıska Türkü, Kuzey Kafkasya’ya özellikle de Krasnodar bölgesine göç etmiştir. Aydıngün ve Aydıngün (2014)'e göre Krasnodar bölgesinde yaşayan Ahıska Türkleri ayrımcılıklara maruz kalmışlardır. Sovyetler Birliği dağılmadan önce bölgeye gelmiş olmaları nedeniyle, Rusya Federasyonu pasaportu alma hakkına sahip olan Ahıska Türklerine oturma izni (propiska) verilmemiş ve bunun bir uzantısı olarak Ahıska Türkleri pasaportsuz kalmış, sonuç olarak devletsiz duruma düşmüşlerdir. Oturma izni verilmemesi Ahıska Türklerinin mülk sahibi olma, yasal olarak çalışma, geçerli herhangi bir kimlik sahibi olma, evlilikleri ve doğumları yasal olarak kaydettirme, emeklilik hakkı gibi temel haklardan mahrum edilmelerine neden olmuştur. Aydıngün (2013), geçerli bir kimlik belgesi olmayan, dolayısıyla pasaportsuz kalan Ahıska Türklerinin maddi olanakları iyi olsa bile seyahat etmelerinin ya da göç etmelerinin imkânsız olduğunu belirtmektedir. Tüm bu anti-demokratik uygulamaların uluslararası örgütlerin dikkatini çekmesiyle Ahıska Türklerinin ABD'ye göç süreci başlamıştır. Ahıska Türklerinin kendi topraklarına dönüşlerinin sağlanamaması da kalıcı çözüm olarak başka bir ülkeye göçü gerekli kılmıştır.

1980 yılında Amerikan Kongresi'nde kabul edilen Mülteci Yasası ve buna bağlı olarak başlatılan ABD Mülteci Programı kapsamında Ahıska Türklerinin Amerika’ya göçmen/mülteci olarak gidebilmeleri sağlanmıştır (Aydıngün ve Aydıngün 2014: 122). ABD Dışişleri Bakanlığı, Krasnodar bölgesindeki Ahıska Türklerinin "vatansız" ve "hiç kimse olma” statüsüne son vermek için 11 Eylül saldırılarından sonra ilk kez "Yeniden Yerleştirme ve İskân” kanun teklifini hazırlayarak Amerikan Kongresi'ne sunmuştur. Ahıska Türklerinin Amerika kanunlarında adı "American Meskhetian Turk” olarak geçmiştir. Ahıska Türkleri için çıkarılan "Özel Kaygılar Göçmen Yasası"na göre, her yıl bütçe döneminde Ahıska Türklerini de kapsayan göçmen grupları ABD'de iskân edilecektir (Aslan 2015: 71-72).

2004 yılında başlayan çalışmalar neticesinde 2006'ya kadar ABD'ye giden Ahıska Türkleri otuzdan fazla eyalete yerleştirilmiştir. ABD'nin Ahıska Türklerini göçmen olarak kabulünde, onlara ilişkin yaptığı araştırmalar etkili olmuştur. Bu araştırmalar neticesinde Ahıska Türklerinin çektikleri acılar, radikal dincilikten uzak olmaları, yaşadıkları ülkelerin yönetimlerine sorun çıkarmamaları, çalışkanlıkları ve yeni ortamlara kolay uyum sağla- 
maları gibi özelliklerinin ABD Mülteci Programı'nın içeriğiyle benzeştiği tespit edilmiştir. 11 Eylül saldırıları sonrasında ABD, Ahıska Türklerini, güvenliğini tehdit etmeyecek göçmen bir topluluk olarak gördüğü için tercih etmiştir (Aydıngün ve Aydıngün 2014: 123-124).

Ahıska Türkleri, 350 ila 400 bin civarındaki nüfuslarıla günümüzde anavatanları dışında Azerbaycan, Gürcistan, Kazakistan, Kırgızistan, Rusya, Türkiye, Ukrayna, Özbekistan ve ABD olmak üzere dokuz farklı ülkede yaşamaktadır (Kahraman ve İbrahimov 2013: 77). ABD’de Ohio, Pennsylvania, Washington DC, Illinois, Kentucky, Arizona, Idaho, Texas, Virginia, New York ve Colorado en yoğun yaşadıkları bölgelerdir (Aydıngün et al. 2006: 26). Araştırma kapsamında analiz edilecek Ahıska Türkleri ise, Florida Eyaleti'nin Jacksonville şehrinde yaşamaktadır. Florida Eyaleti'nde Jacksonville ve Orlando'da olmak üzere toplamda 60 aile yaşamaktadır (http://www. ahiskalilar.org/portal/modules.php? name=News\&file=article\&sid=254).

Bu çalışmada ABD’ye zorunlu olarak göç eden Ahıska Türklerinin kimliklerini oluşturan unsurlar ele alınmaktadır. Kimliğin değişken niteliği göz önüne alınarak, göç edilen mekânda kimliğin nasıl inşa edildiği ve ne tür değişimlere uğradığı soruları da cevaplandırılmaya çalışılmıştır. Ayrıca göç süreci ile birlikte mekânsal olarak kendi kültürlerinden uzakta yaşayan göçmenlerin kendilerini hangi kimlikle tanımladıklarının üzerinde durulmuştur. Çalışma açısından esas olan, araştırmaya katılan kişilerin gündelik gerçekliklerini en doğru şekilde yansıtmaktır.

\section{Ahıska Türk Kimliğinin Göç Sürecinde İnşası}

Göç; dini, iktisadi, siyasi, sosyal ve diğer sebeplerden dolayı insan topluluklarının hayatlarının tamamını veya bir bölümünü geçirmek üzere bir iskân ünitesinden, bir başkasına yerleşmek suretiyle yaptıkları coğrafi yer değiştirme hareketidir (Özer 2004:11). Göç hem göç eden hem de göç alan toplumun yapısında birçok değişikliğe yol açmaktadır.

Göç, nedenlerine (zorunlu-gönüllü), amaçlarına (çalışma-sığınma) ve hedefe varmada kullanılan yönteme (yasal-yasa dışı) göre farklı şekillerde tanımlanmaktadır. Burada, çalışma açısından önemli olan zorunlu ve zincirleme göç üzerinde durulmaktadır. "Savaş, tabi afet, sürgün gibi nedenlerle insanların yaşadıkları yerlerden ayrılmak zorunda kalmaları veya buna mecbur bırakılmaları sebebiyle meydana gelen göç” (Yılmaz 2014: 1686-1687) zo- 
runlu göç olarak tanımlanmaktadır. Zorunlu göçün, bireylerin iradesi dışında gerçekleşmesi, göçmenlerin hem göç edilen yerle ilişkilerini kesintiye uğratmakta, hem de göç edilen yerdeki ilişkilerini etkilemektedir. Zincirleme göç ise, "insanların göç ettikleri yer hakkındaki fikirleri ve göç kararını üyesi oldukları grubun etkisiyle aldıkları göç türü” (Ağır ve Sezik 2015: 98) olarak tanımlanmaktadır. Bu göç türünde, göç edecek bireyler göç sürecinde desteği kendisinden önce göç etmiş olan yakınlarından alırlar. Bir göçmenin aynı anda birden fazla kategoride yer alabileceği göz önüne alındığında $A B D$ ye göç eden Ahıska Türklerinin göçü, zorunlu ve zincirleme göç kapsamında değerlendirilmektedir.

Göç, bireylerin kendi yerel kültür ve kimliklerini yanlarında taşıdıkları bir süreçtir. Bu anlamda kimliğin bazı unsurları muhafaza edilerek bazı unsurları ise değişerek göç edilen mekânda yeniden inşa edilmektedir. Kimliğin yeniden inşasına göçmenlerin toplumsal hafızaları aracılık etmekte ve bu sayede kimliğin yeni kuşaklara aktarılması mümkün olmaktadır. Sözen (1998)'e göre tarihsel süreç içinde oluşan, olgunlaşan, değişen ve dönüşen dinamik bir olgu olan kimlik, aynı zamanda bir sürekliliğin oluşma durumudur. Bu bağlamda çalışmada Ahıska Türklerinin göç süreciyle birlikte Ahıska kimliğinin hangi öğelerini korudukları ve hangi öğelerinin değişime açık olduğunun saptanması da amaçlanmaktadır.

Bir toplumun, halkın ve bir kişinin kendisini nasıl gördüğü, tarihsel ve toplumsal süreçler içinde kendini nasıl konumlandırdığı (Alver 2006: 32) ile ilişkili bir kavram olan kimlik, farklılıklar ve benzerlikler üzerinden tanımlanmaktadır. Barth (2001: 17-18), etnik grupların varlıklarının devamının kültürel davranış açısından farklılıklarını sürdürebildikleri ölçüde mümkün olduğunu belirtmektedir. Ona göre eğer bir grubun üyeleri başka grupların üyeleriyle etkileşim halindeyken kendi grup kimliğini koruyabiliyorsa bu durumda aidiyet ve dışlama dinamikleri devreye girmiş demektir.

Öznel/bireysel ve nesnel/kolektif olarak ikiye ayrılan kimlik, bireysel yönüyle kişiye kendi yerini ve bağlılıklarını hatırlatır, gelenek, görenek ve eğitim yoluyla kişide şuur yaratır, kişiyi ötekilerden ayırt eder ve psiko-sosyal farklılıklarını ortaya koyar. Kolektif kimlik ise grup üyelerinin paylaşılan ortak değerler veya benzerlikler etrafında birleşmesi sonucu oluşur. Kolektif kimlik bir grubun üyelerine ortak anlamlar, bireysel ve sosyal deneyimler kazandırmaya çalışır. Kolektif kimliğin biçimlenmesinde ötekiyle olan ayırt 
edici özellikler ön plana çıkmaktadır (Aka 2010, Yıldız ve Demir 2015). Bu çalışmada Ahıska Türklerinin kolektif kimlik tanımlamaları konu edilmektedir. Bilgin (2007), kolektif kimliği sosyal bir topluluğun diğer topluluklardan farklarını ve özgünlüklerini ortaya koyma talebi olarak tanımlamaktadır. Dolayısıyla kolektif kimlik belirli bir alanda, belli bir kültürel topluluk tarafından taşınan bir kimliktir. Bir grup aidiyeti temelinde oluşan kolektif kimlikler, beraberinde bağlanmayı ve bütünleşmeyi getirmektedir. Sosyal ilişkilerin devamlılığının sağlanmasında kimlik, insanları bir arada tutan sosyal bağ ve harç özelliği taşımaktadır (Karaduman 2010). Böylelikle Ahıska Türklerinin taşıdığı ayırt edici kültürel özellikler çalışma açısından önem arz etmekte ve Ahıska kimliğinin hangi öğelerinin (etnisite, dil ve din gibi) göç süreciyle korunduğu ya da değişime açık olduğu ele alınmaktadır.

\section{Yöntem}

Nitel araştırma yönteminin uygulandığı bu çalışmada, iki araştırma sorusu ele alınmıştır:

1. Ahıska Türklerinin ABD’ye göç sürecinde ve göç ettikten sonra yaşadıkları sorunlar nelerdir?

2. Ahıska kimliğini oluşturan temel unsurlar nelerdir?

\section{Araştırmanın veri toplama araçları}

Araştırmada nitel araştırma yönteminin veri toplama tekniklerinden olan derinlemesine görüşme ve katılımlı gözlem kullanılmıştır. Derinlemesine görüşmeyle Ahıska Türklerinin göç sürecine ilişkin deneyimleri, göç öncesi ve sonrasında yaşadıkları sorunlar, göçün Ahıska Türklerinin kimliklerini şekillendirmedeki rolü ile Ahıska kimliğini oluşturan unsurların kendi deneyimleri ve yorumlarından hareketle anlaşılması amaçlanmıştır. Araştırılan grupla yoğun etkileşimler kurularak, kültürlerini ve gündelik yaşamlarını onların bakış açısıyla anlamak ve kendi bağlamı içinde yorumlamak mümkün olmaktadır. Kümbetoğlu (2005)'na göre, derinlemesine görüşmelerde az sayıda insanla görüşülerek detaylı bilgi elde edilmeye çalışılmaktadır.

Patton (2002) katılımlı gözlem tekniğinin, araştırmacının araştırılan kişilerin aralarına, günlük yaşamlarına ve pratiklerine katılması anlamına geldiğini belirtmektedir. Araştırmacı, araştırdığı kültürün içine girerek, kültür hakkında betimleyici bilgiler elde etmeye çalışır. Bu çalışmada araştırmacı, 
araştırmacı kimliğini açık tutarak, amacının ne olduğunu anlatmış, araştırma süresince onların günlük yaşamlarına mümkün olduğunca katılım sağlayarak onları gözlemlemiştir. Katılımlı gözlem notlarından, Ahıska Türkleriyle yapılan derinlemesine görüşmelerin analizi sırasında yararlanılmıştır.

\section{Araştırmanın veri toplama süreci}

Nitel araştırma yönteminin benimsendiği çalışmanın verileri, 2016 yılının Ocak-Mart aylarını kapsayan sürede Ahıska Türklerinin yaşadıkları Jacksonville'e farklı zamanlarda gidilerek yüz yüze toplanmıştır. Öncelikle araştırmanın yapılacağı alanla ilgili ön çalışma yapılmıştır. Ahıska Türklerinin göç süreci ve kimliklerine ilişkin hazırlanan yarı-yapılandırılmış sorularla gerçekleştirilen görüsşmeler, sosyal ve kültürel ortamlarını daha iyi anlamak açısından gündelik hayatlarını geçirdikleri ev, iş yeri, kahve, park, cami gibi mekânlarda gerçekleştirilmiş, böylece yapılan gözlemlerle daha detaylı veri toplanması sağlanmıştır. Ahıska Türklerinin sosyo-demografik özelliklerine ilişkin bilgilere hazırlanan standart sorularla ulaşılmıştır.

Görüşmeler, katılımcılardan izin alınarak ses kayıt cihazıyla kayıt altına alınmış ve daha sonra bu kayıtlar deşifre edilerek transkriptler birkaç kez okunmuştur. Tüm görüşmeler Türkçe gerçekleştirilmiştir. Ahıska Türklerine konuyla ilgili yapılan açıklamalar sayesinde araştırmaya gönüllü olarak katılmaları sağlanmıştır. Ancak araştırmacının erkek olması, kadınlarla görüşme yapmayı sınırlandırmıştır. Böylece araştırmanın verileri 8 erkek ve 1 kadın olmak üzere toplam 9 Ahıska Türkünün anlatılarından yola çıkılarak toplanmıştır. Her görüşme yaklaşık 3 saat sürmüştür.

\section{Veri analiz süreci}

Wolcott, nitel veri analizinde üç yol önermektedir: Birincisi, toplanan verinin özgün formuna sadık kalarak gerektiğinde araştırmaya katılan bireylerin söylediklerinden doğrudan alıntı yaparak betimsel bir yaklaşımla verileri sunmaktır. İkinci yol, ilkini içerecek bir şekilde bazı nedensel ve açıklayıc1 sonuçlara ulaşmak amacıyla sistematik analiz yapmaktır. Veriler betimsel bir yaklaşımla sunulur, belirlenen bazı temalar ve temalar arası ilişkiler belirlenir. Üçüncü yaklaşımda ise araştırmacı, ilk iki yaklaşımı temel alır ve buna ek olarak veri analizi sürecine kendi yorumlarını dâhil eder (Wolcott 1994'ten aktaran Yıldırım ve Şimşek 2006:156). Çalışmada derinlemesine görüşmelerden doğrudan alıntıların kullanılmasıyla betimsel analizden ve 
verilerden ulaşılan kod-kategori ve temalarla sistematik analizden yararlanılmıştır. Böylece ilk iki yaklaşım temel alınmış ve verilerin analizi sürecine araştırmacının yorumları da eklenmiştir. Veri analiz süreci, veri toplama süreciyle eş zamanlı olarak gerçekleştirilmiştir. Öncelikle araştırma sorularına uygun olarak hangi verilerin kullanılacağına karar verilmiş, veriler düzenlenmiş ve bir araya getirilmiştir. Düzenlenen veriler, katılımcılardan doğrudan alıntılar yapılarak sunulmuş, araştırmacı tarafından kavramsal çerçeve ve gözlemler bağlamında yorumlanarak sonuçlara ulaşılmıştır. Veriler elde edildikten sonra analiz aşamasında, derinlemesine görüşmelerden elde edilen verilerden yola çıkılarak kodlar çıkarılmıştır. Kodlardan 2 kategoriye ve 9 temaya ulaşılmış ve Tablo 1'de gösterilmiştir.

Tablo 1. Ulaşılan Kategoriler ve Temalar

\begin{tabular}{|c|c|}
\hline Kategoriler & Temalar \\
\hline & Ayrımcılık \\
\hline & Zorunlu göç \\
\hline & Zincirleme göç \\
\hline & Yaşanılan sorunlar \\
\hline Göç süreci & Türkiye'ye kırgınlık \\
\hline & Kimlik bilinci \\
\hline & Türklük \\
\hline Ahıska kimli- & Türkçe \\
\hline gimm unsuriari & Müslümanlık \\
\hline
\end{tabular}

\section{Katılımcılar}

Görüşme yapılacak bireylerin seçiminde, araştırma konusuyla doğrudan ilgili olup olmadıkları ve gönüllülük esası dikkate alınmıştır. Katılımcılara verilen söze sadık kalınarak gerçek isimleri kullanılmamış, katılımcılar kodlanmıştır. Katılımcıların sosyo-demografik özellikleri genel itibariyle Tablo 2 gösterilmektedir. 
Tablo 2. Katılımcıların Sosyo-Demografik Özellikleri

\begin{tabular}{|c|c|c|c|c|c|c|c|c|}
\hline $\begin{array}{l}\text { Kat1lim- } \\
\text { cılar }\end{array}$ & Doğum yeri & Yaş & $\begin{array}{l}\text { Medeni } \\
\text { durum }\end{array}$ & $\begin{array}{l}\text { Eğitim } \\
\text { durumu }\end{array}$ & $\begin{array}{l}\text { Ort. } \\
\text { aylik } \\
\text { gelir }\end{array}$ & $\begin{array}{l}\text { Kimlerin } \\
\text { çalıştığ } 1\end{array}$ & $\begin{array}{l}\text { Kiminle } \\
\text { yaşadığ } 1\end{array}$ & Meslek \\
\hline K 1 & Özbekistan & 57 & Evli & Üniversite & $\begin{array}{l}6500 \\
\text { dolar }\end{array}$ & $\begin{array}{l}\text { Kendisi, } \\
\text { oğlu, } \\
\text { gelini }\end{array}$ & $\begin{array}{l}\text { Eşi, oğlu, } \\
\text { gelini, iki } \\
\text { torunu }\end{array}$ & $\begin{array}{c}\text { Uçak } \\
\text { mühendisi }\end{array}$ \\
\hline K 2 & Özbekistan & 56 & Evli & Üniversite & $\begin{array}{l}3000 \\
\text { dolar }\end{array}$ & $\begin{array}{l}\text { Kendisi, } \\
\text { oğlu, } \\
\text { gelini }\end{array}$ & $\begin{array}{l}\text { Eşi, oğlu, } \\
\text { gelini }\end{array}$ & $\begin{array}{c}\text { İnşaat } \\
\text { mühendisi }\end{array}$ \\
\hline K 3 & Özbekistan & 60 & Evli & Üniversite & $\begin{array}{l}3800 \\
\text { dolar }\end{array}$ & $\begin{array}{l}\text { Kendisi, } \\
\text { oğlu, } \\
\text { gelini }\end{array}$ & $\begin{array}{l}\text { Eşi, oğlu, } \\
\text { gelini, iki } \\
\text { torunu }\end{array}$ & $\begin{array}{c}\text { İnşaat } \\
\text { mühendisi }\end{array}$ \\
\hline K 4 & Özbekistan & 63 & Evli & İlköğretim & $\begin{array}{l}3500 \\
\text { dolar }\end{array}$ & $\begin{array}{c}\text { Kendisi, } \\
\text { oğlu, } \\
\text { gelini }\end{array}$ & $\begin{array}{l}\text { Eşi, oğlu, } \\
\text { gelini, iki } \\
\text { torunu }\end{array}$ & İşçi \\
\hline K 5 & Özbekistan & 50 & Evli & İlköğretim & $\begin{array}{l}3000 \\
\text { dolar }\end{array}$ & $\begin{array}{l}\text { Kendisi, } \\
\text { eşi, oğlu }\end{array}$ & $\begin{array}{l}\text { Babası, eşi, } \\
\text { oğlu, gelini, } \\
\text { iki torunu }\end{array}$ & İşçi \\
\hline K 6 & Özbekistan & 58 & Evli & Yüksekokul & $\begin{array}{l}3500 \\
\text { dolar }\end{array}$ & $\begin{array}{l}\text { Kendisi, } \\
\text { eşi, gelini }\end{array}$ & $\begin{array}{c}\text { Eşi, iki } \\
\text { oğlu, gelini, } \\
\text { iki torunu }\end{array}$ & İşçi \\
\hline K 7 & Özbekistan & 48 & Evli & Üniversite & $\begin{array}{l}3700 \\
\text { dolar }\end{array}$ & $\begin{array}{l}\text { Kendisi } \\
\text { ve iki } \\
\text { oğlu }\end{array}$ & $\begin{array}{c}\text { Eşi, iki } \\
\text { oğlu, gelini, } \\
\text { iki torunu }\end{array}$ & İşçi \\
\hline K 8 & Özbekistan & 50 & Evli & Üniversite & $\begin{array}{l}3500 \\
\text { dolar }\end{array}$ & $\begin{array}{l}\text { Eşi ve } \\
\text { kendisi }\end{array}$ & Eşi iki oğlu & Tesisatçı \\
\hline $\begin{array}{c}\text { K } 9 \\
\text { (Kadın) }\end{array}$ & Kazakistan & 65 & Bekâr & Lise & $\begin{array}{l}4000 \\
\text { dolar }\end{array}$ & $\begin{array}{c}\text { Kardeşi } \\
\text { ve karde- } \\
\text { şinin eşi }\end{array}$ & $\begin{array}{c}\text { Kardeşi ve } \\
\text { kardeşinin } \\
\text { eşi ve iki } \\
\text { çocuğu }\end{array}$ & İşsiz \\
\hline
\end{tabular}

9 kişiden oluşan katılımcıların biri kadın, diğerleri erkektir. Kadın katılımcının 1 kişi olmasının nedeni, derinlemesine görüşmeleri gerçekleştiren araştırmacının erkek olması ve görüşmelerin gönüllülük esasına dayanmasından ötürü kadınların araştırmaya katılmaya gönüllü olmamalarıdır. Diğer nedeni ise Ahıska ailesinin ataerkil yapıya sahip olmasıyla ilişkilidir. Yüzbey (2008:684) de bu duruma işaret ederek, Ahıska ailesinde kadına söz hakkı tanındığını fakat son sözü erkeğin söylediğini ifade etmektedir. Bu bağlamda kadınlarla ilgili bilgilere genel olarak erkeklerle yapılan görüşmelerden ve katılımlı gözlemden ulaşılmıştır.

Katılımcıların birisi hariç tamamı Özbekistan doğumludur. En genci 45, en yaşlııı 63 yaşındadır. Ahıska Türklerinin evde kimlerle yaşadıklarına ba- 
kıldığında, aile yapısının geleneksel geniş aile olduğu görülmektedir. Buna göre en küçük erkek çocuk, evlendikten sonra eşi ve çocuklarıyla birlikte anne-babasının evinde yaşamaya devam etmektedir. Görüşmelerden anlaşıldığı üzere, iki ailenin gelirleri ortak olacak şekilde babanın elinde toplanmaktadır. Aile yapısıyla ilgili bulgular, Yüzbey (2008)'in bulgularıyla örtüşmektedir. Ailede yaşa göre hiyerarşi bulunmaktadır. Ahıskalı Türklerin bazı kuralları vardır. Yeni gelin aile büyükleri izin verene kadar, büyüklerle özellikle de erkeklerle konuşmaz. Ayrıca Ahıska Türkleri arasında endogaminin yaygın olduğu gözlenmiştir.

Katılımcılardan ikisi ilköğretim, biri lise, biri yüksekokul ve dördü üniversite mezunudur. Katılımcılardan biri hariç hepsi ve geniş aile üyeleri bir işte çalışmaktadır. Kolukırık (2011: 182) da Ahıska Türkleri arasında işsizlik sorunu bulunmadığını, bunun sebebinin kolay ya da zor iş ayrımı yapmamaları ve çalışmanın kutsallığına inanmaları olduğunu belirtmiştir. Erkek katılımcıların çoğu tersanede gemi yapımında, araba tamirinde ya da markette işçi olarak çalışmaktadır. Kadınların ise temizlik işi yaptıkları ya da marketlerde çalıştıkları öğrenilmiştir.

\section{Araştırma Sorularının Temalar Çerçevesinde Analizi}

Bu başlık altında araştırmanın soru cümleleri, ulaşılan temalar çerçevesinde analiz edilmiştir. Problem cümleleri bağlamında verilerden çıkartılan temalar, konuyla ilgili literatür bağlamında analiz edilip araştırmacının gözlemleri doğrultusunda yorumlanmıştır. Verilerin analizi kapsamında; kod, kategori ve temaların belirlenmesine ilişkin Microsoft Excel programı aracılığıyla hazırlanan transkript yöntemi kullanılmıştır. Bu bağlamda katılımcıların ifadelerine bakılarak temaların ne sıklıkta kullanıldıkları görüşme analizlerinden önce grafikler aracılığıyla gösterilmiştir.

\section{Göç süreci}

Ahıska Türklerinin göç süreci analiz edildiğinde ulaşılan temalar, sıklıklarıyla birlikte Grafik 1'de yer almaktadır. Buna göre yapılan görüşmelerde en fazla vurgulanan tema, Amerika’ya göç etmeden önce Krasnodar bölgesinde yaşadıkları ayrımcılık iken, göç süreciyle ilgili en az vurgulanan tema ise kimlik bilinciyle ilgilidir. 


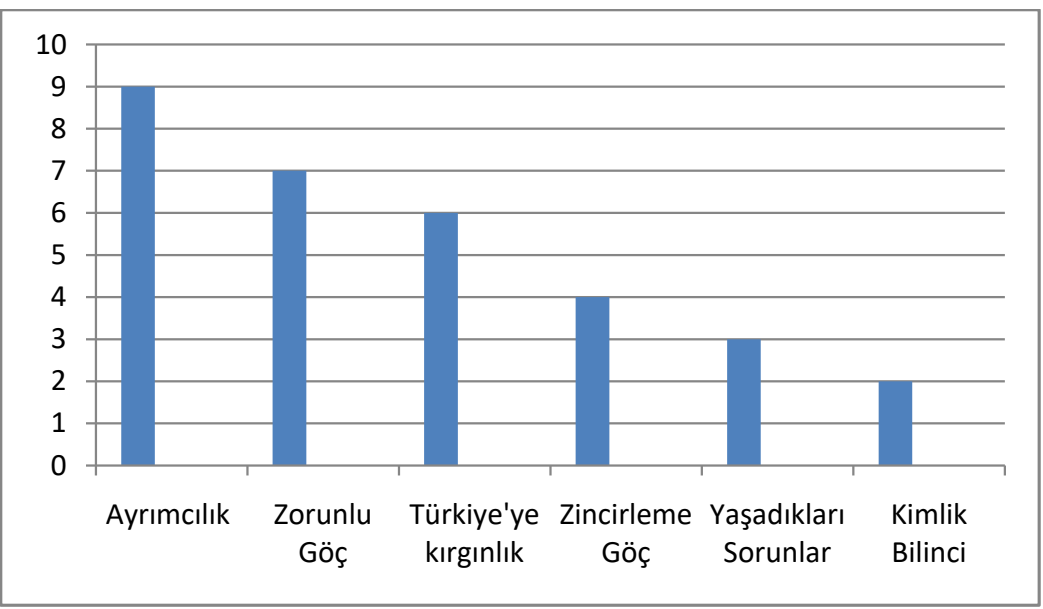

Grafik 1. Ahıska Türklerinin Gö̧̧ Süreciyle İlgili Olarak Ulaşılan Temalar

Ahıska Türkleri sadece etnik kökenleri, tarihleri, gelenekleri, yaşam biçimleri ve kullandıkları Türkçeyle değil; karşılaştıkları sorunlarla da dikkat çekmişlerdir (Yüzbey 2008: 681). Ahıska Türklerinin tarihi göçlerle şekillenmiştir, bu nedenle öncelikle göç süreçleri ve göç sürecinde yaşadıkları sorunlar analiz edilmiştir. Ahıska Türkleri Krasnodar'da yaşadıkları ayrımcılık ve zorunlu gọ̧̈ süreci ile ilgili olarak şu şekilde görüşler belirtmişlerdir:

Dünya devletlerine mektup yazdlk bize yardım edin diye, sadece Avustralya ve Amerika cevap verdi. Amerika'dan geldiler tercüman vasitasıyla bizimle konuştular. Neler yaşadığımızı anlattık. Soruyorlardı Amerikaya niçin gitmek istiyorsun. Üniversiteye gidip pilot olmak istediğimi fakat o bölümü okuma izni vermediklerini anlattım. Benden sonra ne hanımı ne çocukları sordu gidiyorsunuz dedi çıktı gitti. Amerika bizi kabul etti mecbur 2006 ynlında buraya geldik. (Katılımc1 1, 57, uçak mühendisi)

Katılımcının da ifade ettiği gibi, Krasnodar'da yaşayan Ahıska Türklerinin ayrımcılık yaşadıkları konulardan birisi, eğitim haklarının engellenmesiyken, üniversiteyi başka bir ülkede okuyanlar ise iş bulma sorunu yaşamışlardır:

Kardeşlerimin biri elektrik mühendisi, diğeri mimar ama bize iş vermiyorlard. Ancak tarlalarda çallşıp pazarda yetiş̧tirdiklerimizi satabiliyorduk. Onlarm bize yaptığı bu zülüm çekilecek gibi değildi. Evlerimiz vardi ama tapusu yoktu, hepsini sattzk bir tavuk fiyatına. Krasnodar'da 
gün yüzü görmedik. Bizi 2005 ynlında Amerika’ya getirdiler. (Katılımc1 9,65 , işsiz)

İssizlik sorunun yanı sıra Krasnodar'da diğer bir sorun Ahıska Türklerine vatandaşlı verilmemesiyle ilişkilidir:

2005 yılinda buraya geldik, Rusya'da kimlik, vatandaşlik vermiyorlardr. Yaşamımızı her türlü zorlaşttriyorlardı. Çalışmak istiyorduk iş vardı ama Ahıskalı olduğumuz için bizi almıyorlardr. Niye? Türksü̈n, Müslümansin! Tarla alıyoruz, tapuyu kendi adımıza alamıyorduk eski sahibinin adında kaliyordu. Yani tarla senin ama iş̧̧i gibi çallş̧yorsun orda. (Katılımcı 6, 58, işçi)

Yaşadıkları ayrımcılığı Türk ve Müslüman olmalarına bağlayan Ahıska Türkleri, yaşadıkları ülkenin vatandaşlı̆ııı alamadıkları için bazı sorunlar yaşadıklarını belirtmişlerdir:

Özbekistan'da yaşıyorduk, çoğumuz okumuştu, herkesin bir mesleği vardı ama is vermiyorlardı bize. Pazarlarda ve tarlalarda kısa süreliğine çalışabiliyorduk. Biliyorlar biz Türk’üz çok ihtiyaçları varsa bizi çalıştırıyorlardı yoksa Özbekler çalışıyordu. Her gün bize gidin buradan diyorlardi. Babamız dedemiz gelmiş Ahıska'dan buraya, biz burada doğmuşuz ama yine de gidin diyorlardı. O kadar Ahıskalı yaşıyor orda ama hiçbirisinin evi yok yani var ama kendi üzerlerine değil. Tapusu ya Rusların ya da Özbeklerin üzerine oluyordu. Hayat bizim için çekilmez olmuştu orda. (Katılımcı 7, 48, iş̧̧i)

Katılımcı 8'in ifadeleri de Amerika'ya göç etmeden önce ayrımcılık yaşadıklarını doğrulamaktadır:

Biz daha önce Özbekistan'da yaşıyorduk. Oradan Krasnodar'a gittik, yaklaşı 10 sene kaldık. Oradan da buraya geldik. Krasnodar'da bize gün vermiyorlardr. Kara adamlar diyorlard, eziyet ediyorlard, doktora gidemiyorduk kâğgdımız (kimlik) yoktu. Rusya da bir şehirden başka bir şehre gidinceye kadar 10 tane polis durduruyor, para istiyor, kimsin, nereye gidiyorsun diye soruyordu. (Katılımcı 8, 50, tesisatçı)

Ahıska Türkleri, pasaport sahibi olamama, işsizlik, mal-mülk sahibi olamama gibi hukuksal ve ekonomik problemlerinin yanı sıra yaşadıkları sorunların bir diğerini güvenlik kaygısı olarak ifade etmişlerdir: 
2006 yllinda geldim buraya. Bize zülüm ediyorlard. Bize vatansızsını, gidin buralardan diyorlardı. (Katılımcı 2, 56, inşaat mühendisi)

Krasnodar'da pasaport yok, izin vermiyorlar orda yaşamaya. Oranın güvenliği yok, her gün burada yer yok gidin nereye giderseniz gidin diyorlardr. Yaşamak kıyım oldu. (Katılımc1 4, 63, işçi)

Görüldüğü gibi, Ahıskalıların ABD’ye göç etme kararlarında can güvenliklerinin olmaması etkili olmuştur:

2005 tarihinde Rusya'dan geldim buraya. Bizi açık açık kırmaya, öldürmeye baslladılar. Adam geliyor atıyor (sıkıyor) gidiyor. Onun mahpusu yok hiçbir şeyi yok. Bütün dünyaya sahip çıkın diye mektup yazıldı. $O$ memleketlerin hiçbiri, hiçbir Müslüman memleketi içinde Türkiye de mektuplara cevap bile vermedi. Ama Amerika bizi işitti: Gelip burada kongrede bunu söyleyebilir misiniz? diye cevap geldi. Geldik kongrede bunları söyledik ondan sonra bizi Rusya'dan buraya alma kararı verildi. Biz 12.000-13.000 Ahıska Türkünü refugee (sı̆̆gnmacı) olarak aldılar. (Katılımcı 3, 60, inşaat mühendisi)

Yaşadıkları ayrımcılık ve can güvenliklerinin olmaması sebebiyle uluslararası camiada sorunlarına çözüm bulmaya çalışan Ahıska Türkleri, yaşadıkları topraklardan ABD'ye göç etmek zorunda kalmışlardır:

Krasnodar bölgesinden geldik buraya. Zülüm görüyorduk, is vermiyorlardı evin yok alamiyorsun, is bulursan az para veriyorlar. Devletlere mektup yazdık ama kimseden cevap gelmedi. Sonra Uluslararası Gög Organizasyonu bizi refugee (sı̆̆ınmacı) olarak kabul etti. (Katılımcı 6, 58, işçi)

Çabaları sonuç veren Ahıska Türkleri, 2005 yılı itibariyle ABD’nin çeşitli eyaletlerine göç etmeye başlamışlardır:

Hiçbir yer sahip çıkmadı, Ahıska Türkleri çok zülüm gördü. Ondan sonra Amerika’ya başvurdular, Amerika aldı bizi. Săg olsun Amerika bizim insanlara yardım etti. (Katılımcı 5, 50, işçi)

Uluslararası Gö̧ Örgütü ile beraber Amerikalılar geldiler bizim belgeleri incelediler. Durumlarmıza baktılar sonra bizim liderlere gelin dertlerinizi Amerika'nin parlamentosunda anlatın dediler. Bizim liderler geldi Bush zamanında anlattılar neler yaşamışız. (Katılıma 7, 48 yaşında, işçi) 
Katılımcılardan bazıları, Türkiye'ye göç etmek istediklerini fakat Türkiye’nin Ahıska Türklerinin göç sürecinde yardımcı olmadığını ve bu nedenle Türkiyejye kırgın oldukların ifade etmişlerdir:

Devletlere başvurduk yardim edin bize diye sadece $A B D$ cevap verdi. Ne Türkiye ne başka bir devlet cevap bile vermedi. Biz de buraya geldik. Yani evin yanıyor su getirip söndürmeye çalışan kim olursa olsun, yardimi alırsin. Herkes de buraya gelmedi, korktular bazılar ama sonra bir kısmı daha geldi. Bak burada evimiz var, herkesin 1-2 arabası var kimse kimseye karışmıyor. Buraya gelmeyelim de nereye gidelim. (Katılımcı 6, 58, işçi)

Türkiye o vakitlerde hiç sahip çıkmadı bize şimdi sahip çıkmaya çalışıyor. Türkiye'den hiç kimse gelip bu millet bizim kardeşimizdir demedi. Şimdi evler yapmışlar, çağırıyorlar. (Katılımcı 8, 50, tesisatçı)

Başka gidecek yerimiz yoktu ki gidelim. Başka devletler almadı bizi Türkiye de almadı, Amerika sahip çıktı bize, getirdi. Kaç kere ev kurduk Özbekistan'da, Rusya'da ama hepsinde de sürgün olduk. Ne bilelim belki bir gün buradan da sürgün oluruz. (Katılımc1 9, 65 yaşında, işsiz)

Katılımcı 9'un ifadesinden ontolojik anlamda güvende hissetmediği görülmekte, her an sürgün edilebileceğini düşünmektedir. Katılımcılardan bazıları ABD'deki yaşamlarından memnun oldukları için Türkiye'ye göç etmediklerinden üzüntü duymasalar da bazıları yaşadıkları üzüntüyü ve $k \imath r-$ ginlıkların dile getirmektedir.

Biz aslinda yardım, imdat şeyini Türkiye'den bekliyorduk. Şimdi sahiplik ediyor ya Ahıskalılara, ihtiyacımız yok o zaman sabiplik etseydi, yok olmadı bu işler hiç olmadı. (Katılımcı 3, 60, inşaat mühendisi)

Ahıskalılar, ABD’ye göç ederken daha önce oraya göç etmiş akrabalarının bulundukları eyalete göç etmek istemişlerdir, Ahıska Türklerinin göç türü zincirleme gö̧s olarak değerlendirilebilir:

Kardeşlerimi takip ettim buraya geldim. Bize bir akrabanız var mi, Amerika'nin neresine gitmek istiyorsun? diye sordular benim de akrabalar buraya geldiğgi için buraya geldim. (Katılımcı 2, 56, inşaat mühendisi) 
Bize sordular nereye gitmek istersiniz bir akrabanız var mı Amerika'da diye. (Katılımcı 3, 60, inşaat mühendisi)

Ahıskalılar toplandık, düşündük daha önce akrabalarımız gelmişti. Benle babam geldik ilk önce sonra çocuklar geldi. (Katılımcı 6, 58, işçi)

Akrabalar ilk önce geldiler, Amerika’nın iyi olduğunu söylediler, geldiklerinde devlet onlara iş vermiş, kiralarmı vermiş her şeyi devlet karşılamış. Bize de anlattılar buraya geldik. İlk Ahıskalılar nereye gittiyse diğerleri de oraya gider, biz ayn yerde yaşarız. Bak Jacksonvilleee, bütün Ahıskalılar ayn bölgede yaşıyor. (Katılımcı 7, 48, işçi)

Ahıska Türklerinin ifadelerinden zincirleme göçün nedenlerinden birisi olarak önemini koruyan geleneksel aile bağları karşımıza çıkmaktadır. Zincirleme göçün diğer bir nedeni ise daha önce buraya göç eden akrabalarının yaşam biçimlerinden memnun olmalarıdır. Göç etmeden önce sosyo-ekonomik açıdan birçok sorun yaşayan Ahıska Türkleri daha fazla sorun yaşamak istememekte, bu nedenle akrabalarından aldıkları bilgilerle rahat yaşayacaklarını düşündükleri yerlere göç etmek istemektedirler.

Aslinda ben gelmeyeceğim dedim buranın nasıl bir yer olduğunu bilmiyorduk. Dinimiz farkl, dilimiz farkl, İngilizceyi bilmiyoruz. İlk gelen Ahıskalilar 2005 yılında geldiler. Benim akrabalarım falan geldi ilk buraya. 6 ay sonra biz de gelmeye karar verdik ama sıkıntılar falan çıktı ancak 2007 ynlında gelebildik. (Katılımcı 7, 48, iş̧i)

Ahıska Türklerinin göç süreci ile ilgili dikkat çeken diğer bir konu, kimlik bilinciyle ilgilidir. İki katılımcı coğrafi olarak daha yakın ülkelere göç etme imkânları olduğu halde, bu ülkelerin Türklüklerinden vazgeçmeleri şartıyla onları kabul ettiğini ve bu nedenle hiç bilmedikleri uzak bir ülkeye göç etmeyi tercih ettiklerini belirtmişlerdir.

Gürcistan'a gidelim dedik Ahıskaya onlar kabul ediyordu fakat diyordu ki Türklügünüzzü bırakın öyle gelin. İsimlerimizi değģstirecekti, soyadlarımızı Gürcü yapacaktı. Biz de kabul etmedik. (Katılımcı 6, 58, işçi)

Gürcistan, Türklüğünüzden vazgeçin öyle kabul ederim diyordu, biz de kabul etmiyorduk. (Katılımc1 2, 56, inşaat mühendisi)

Ahıska Türklerinin göç ettikten sonra yaşadıkları sorunlar da görüşmelerde ortaya çıkmıştır. Bu sorunlar ABD'nin Ahıskalı göçmen almayı durdurması 
nedeniyle, Rusya'daki akrabaları için duyulan özlem ve dil bilmemeleridir. Yaşlı olanlar İngilizce bilmemekte, dolayısıyla yazılı sınavı geçseler dahi mülakatlarda İngilizce konuşamadıkları için Amerikan pasaportu alamamakta ve akrabalarını ziyaret etmek için yurt dışına çıkamamaktadırlar.

Özbekistan'da, Rusya'da babalarımız, kızlarımız, akrabalarımız kaldı çok gitmek istiyoruz yanlarına ama pasaportumuz yok. (Katılımc1 5, 50 , işçi)

Geldik 5 gün sonra işe gittik, zordu dil bilmiyordum. Sonra dili biraz ögrendik. Çocuklar daha çabuk ögrendi, bizim için çetindi. Hanım da dili ögrenemedi ama çalş̧ıyor. Üzüliüyor çünkü Rusya'da anası, kardeşleri, babası var. Rusya'ya gider de geri gelemez pasaportu olmadiğg için. (Katılımcı 6, 58, işçi)

Ben Türkiyeje hiç gitmedim, akrabalarımız var orada. Benim pasaportum yok o yüzden gidemiyorum. Pasaport almak için iki kere yazıl sinavı geçtim ama sözlü sınavı geçemedim. (Katılımcı 2, 56, inşaat mühendisi)

Bir sıkıntımız var pasaport alamıyoruz. Yani yaşlılarımız için zor ama gençler İnilizceyi daha iyi biliyorlar pasaport daha kolay aliyorlar (Katılımc1 4, 63, işçi)

\section{Ahıska kimliğinin unsurları}

Etnik ve kültürel kimlik, sosyalizasyon süreciyle kuşaktan kuşağa aktarılmakta, böylece kültürel süreklilik sağlanmaktadır. Schonpflug (2009), geleneksel olarak değişimin yavaş gerçekleştiği toplumlarda birincil kuşakların mevcut kültürün muhafazası ve aktarılması konusunda ısrarcı olduklarını, kültürel yeniliklerin ise çoğunlukla genç kuşaklar aracıllğıyla sağlandığını belirtmektedir. Katılımcıların Amerika’ya göç eden birinci kuşağı kapsadığı bu çalışmada Ahıska Türkleri ile yapılan görüşmelerden Ahıska kimliğinin unsurları olarak Türklük, Türkçe ve Müslümanlık olmak üzere üç temaya ulaşılmıştır. 


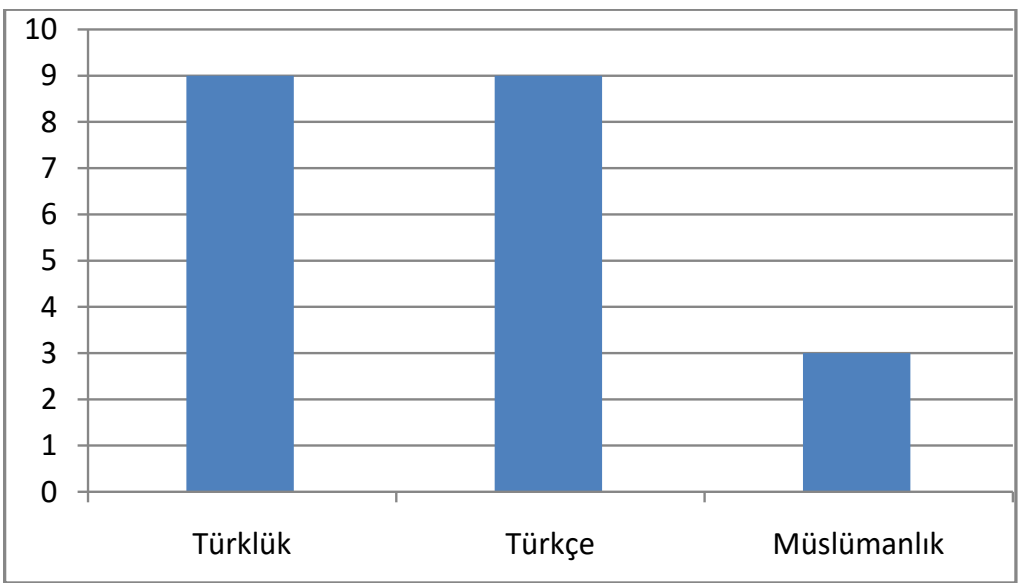

Grafik 2. Ahıska Kimliğini Olușturan Temel Unsurlar

\section{Türklük}

Grafikte de görüldüğü üzere Ahıska Türklerinin hepsi kendilerini "Türk" olarak tanımlamaktadır. Yüzbey (2008: 681) de Ahıska Türklerinin kendilerini Osmanlı Türkü olarak tanımladıklarına ve sosyal hayatlarında Türk kültürünün baskın olduğuna, Gürcüoğulları gibi birtakım yakıştırmaları kabullenmediklerine dikkat çekmektedir. Katılımcıların ifadelerine bakıldığında kendilerini Türk olarak tanımlama ve Türklügün atalarından miras kaldığı görüşü yaygındır:

Ben Ahıskalı demiyorum her yerde Türk'üm diyorum. Rusya'da soruyorlardı diyordum 'Turuk'. Özbekistan'da Türkmen diyordum. Burada da 'I'm Turkish' diyorum, 'T'am from Russia' dersen onlar hemen sen Rus'sun derler. Anam babam Türk olduğuna göre Türk’üm nasil başka millet derim. Atalarımız Türk'üz dediler onu devam ettiriyoruz. Kendi dilimizi konuşuruz. Yani bu bizim kimliğimiz, Gürcü olsaydık Gürcüce konuşurduk. Kimliğimiz bizim kültürümüz, örf âdetimizdir. Bizim kültürümüz bizim kimliğimizdir. Kültürümüzü kaybedersek kimliğimizi de kaybederiz. Kültür olmadan kimlik ne işe yarar ki, hiçbir işe yaramaz. (Katılımcı 6, 58, işçi)

Ben tabi ki de Türküm. Tamam, Ahıska Türküuyüm ama orası sadece bizim dedelerimizin yaşadiğz yerin adı. Nerde soruyorlar sorsunlar 
Türküm diyorum. Bu bizim karar verdiğimiz bir şey değil ki, elhamdülillah Müslümanım ama önce Türkü̈m. Allah beni Türk olarak yaratmış, değişstiremem. Bizim burada olmamızın sebebi de Türk olmamız. Kimliğimizden vazgeçmedik o kadar zülüm gördük ama yine de Türk kaldık. Bizim Türklüğ̈̈müz bizim âdetimiz, babalarımız, dedelerimiz demek. Bak Müslümanlık öyle değil. Özbekler de Müslümandı ama kültürümüz farklıydı. Ne kızımızı veriyorduk ne kız alıyorduk çünkü Türklük çok farklı bir şey. Rusya'da Müslümanlık biraz farkliydı çünkü orda Türk demek Müslüman demekti yani ikisini ayırmıyorlardı. Biz yine de Türk diyorduk kendimize. (Katılımc1 7, 48, işçi)

Katılımcı 6 ve 7’nin ifadeleri, etnik kimliğin primordialist bir bağ olarak kabul edildiğini gözler önüne sermektedir. Etnisite kuramları arasında yer alan Geertz (1963) ve Shills (1957)'in çalışmalarında öne çıkan primordialist yaklaşım, etnik kimliğin tanımlanmasında kan bağını temel alır. Bu yaklaşıma göre etnik kimlik, bireyin üyesi olduğu grubun özelliklerine göre tanımlanmakta, bireysel iradenin dışında ve bireye zorlayıcı bir özellik taşımaktadır. Bu anlamda etnik kimlik, doğuştan verili ve süreklilik taşıyan, değişmez niteliklerle (kan, ırk, dil, din gibi) tanımlanmaktadır. Geertz, primordial bağlılıkları, birinci dereceden akraba bağlantılarını esas alan, ancak bunların ötesinde belli bir dinsel topluluk içinde doğmaktan, belli bir dili ve hatta bu dilin bir ağzını konuşmaktan, belli sosyal uygulamaların yarattığı sosyal varoluşun verilerinden kaynaklanan bağlılıklar olarak tanımlar. Bu bağların, varlığı ve doğruluğu sorgulanmaksızın kabul edilir. Katılımcılar, Türk olmalarını atalarının Türk olmasına, başka bir ifadeyle Türklüğün kan bağına ve doğumdan itibaren var olmasına bağlarlar. Türklük, kimliklerinin verili ve değişmez bir parçasını oluşturmaktadır. Onlara göre etnik kimlik dil, din, gelenek gibi kültürel öğelerle sarmalanmıştır ve birey bu kimliklerini değiştirme iradesine sahip değildir.

Özbekistan da Rusya'da soruyorlardı Türk diyorduk. Ben kimseden gizlememişim, çünkü adın ne deyince 'İlam' adın verince onlar anliyorlardi zaten. Şimdi Türklük bize babalarmızdan geliyor. Babalarmız biz Türküz diyorlard, biz de böyle diyoruz. Biz Türklügümüzden vazgeçmeyiz, vazgecseydik Gürcistan'da olurduk. Bize dediler ki kimliğinizden Türkü silin yerleşin Gürcistan’a diye (eski vatanlar, dedeleri buradan sürülmüs) o şartlarda kimse Gürcistan'a gitmedi. Bak benim soyadım 'Alı- 
şan'dur, Gürcü olunca 'Alışanitze' edeceklerdi. Öyle deģ̆̈şecektik (asimile olacaktık). (Katılımcı, bu bilgileri paylaşmamızda sakınca olmadığını belirtmiştir) (Katılımcı 1, 57, uçak mühendisi)

Türk kimliğinin vazgeçilmez olduğunu ifade eden Katılımcı 1, içinde bulunduğu durum her ne olursa olsun kimlik tanımının değişmeyeceğini belirtmektedir. Benzer ifadelere Katılımcı 2'de de rastlanmaktadır:

Çoktandir Türkiyeli arkadaşlar bu suali soruyorlar bana. Ben Türkiyeli bir Türk'e sorduğumda Türk müsün? diye bana Türkiyeli Türküm demiyor ki sadece Türk’üm diyor. Bizim yaşadı̆̆ımız yerin adı Ahıska, yoksa biz Türk’üz. Türk diyoruz kendimize Ahıskalı Türk değil. 10 tane Ahıskalının 8'inde bu ay hilal var (omuzunu açıyor ve ay yıldız dövmesini gösteriyor). Ne demek bu Türkoğlu Osman. Bu Türklüğ̈̈müzün bir nişanesi. Oğlumda da var bundan. Kimliğimiz kü̧̈üklüğ̈̈müzden kalmadir. Köylerimizin isimleri Türkçe idi Aktepe, Karabă̆gibi. (Kat1$\operatorname{lımcı} 2$, 56, inşaat mühendisi)

Katılımcı 2 ve Katılımcı 3, kimliklerini tanımlarken Osmanlı vurgusu yapmışlardır:

Ben Ahıska Türküyüm istesem de istemesem de. Osmanl torunuyum, Osmanl Türklerindeniz. Eee! Ahıska kimin yeri idi tarih vaktinde? Kimden kaldn? Türkiye mi diyorlardı oraya, demek biz de Türkü̈z. Değiştiremiyorsun yani. Türk’üm ama Ahıska'da yaşıyorum bu yaşadığım yerim Bursa, İstanbul gibi ama Türklüğ̈̈mü kimse kolumdan almamış ki (kolundaki ay-yıldız dövmesini kastederek) kardaşım. Bu bizim kolumuzdan Türklüğümüzü almak için nice nice işler oldu, kişiler geldi geçti. Sen Gürcü Müslümanısın dediler. Ahıska bizim yaşadı̆ğmız yerin adı. Türk Türk'tür. Ben o adımın değģşmemesi için kanlar dökmüşüm. Sen dişardan bakıyorsun Ahıskalı diyorsun ben o adrm tkaybetmeyeyim diye nice nice 1000 adamlarım gitmiştir (Katılımc 3, 60, inşaat mühendisi).

Katılımcı 2 ve 3, kollarına yaptırdıkları dövmeyle hem içsel olarak duyumsadıkları kimliği dışarıya vurmakta, hem de duyumsadıkları kimliğin herkes tarafından bilinmesini istemektedirler. Türklüğe yapılan vurgu diğer katılımcıların ifadelerinde de görülmektedir:

Türk'üz diyoruz kendimize. Ahıskalı Türk’üz. Ahıska bizim dedelerimizin yaşadiğı yer yoksa biz Türk’üz. Bize Türk diyorlardı Ahıska'da, 
Rusya'da ve Özbekistan'da. Ne zaman ki biz Amerika'ya geldik olduk Ahıskalv. Bize kimse Ahıska Türkü demiyordu buraya geldik böyle bir şeyi icat ettiler. Biz Türk idik, Mesketi diyorlardr, Mesketi yaşadiğgnız toprağın adıyd. Şimdi olduk Ahıskalı. (Katılımcı 8, 50, tesisatçı)

Katılımcı 8, Ahıska’nın coğrafi bir bölge adı olduğuna dikkat çekmektedir. Amerika'ya gelene kadar Türk olarak tanımlandıklarını, Amerika'ya geldikten sonra ise Ahıska Türkü olarak tanımlandıklarını ve bu tanımlamadan rahatsız olduğunu belirtmiştir.

Hakiki Türk’üz. Kendimizi Türk hissediyoruz ne yapsak da bu değigmez başka milletten gelmedik ki. Zaten Türk olduğumuzdan dolayı her yerden sürgün oluyorduk. Ahıskày da Amerikajya gelince ögrendik biz Türk’üz diyoruz Türkiyeli Türkler yok siz Ahıska Türküsünüz diyorlar. (Katılımc1 9, 65, işsiz)

\section{Türkçe}

Çalışmada dil, bireylerin topluluk içi ve topluluk dışı etkileşimlerini şekillendiren, kültürel kimliğin nesilden nesile aktarımını sağlayan kültürel kimliğin bir unsuru olarak ele alınmaktadır. Önder (2002), anadil ve ikinci dil gibi unsurların etnik grup bilincinden çok, kökeni açıklaması bakımından önem taşıdığını belirtmektedir. Ahıska Türkleri, Doğu Anadolu ağzına yakın bir Türkçeyle konuşmaktadır (Yüzbey 2008: 681). Aliyeva (2015: 438) da Ahıska Türklerinin konuşma ağzı olarak Ahıska bölgesine yakın Ardahan, Olur, Oltu ve Şenkayada konuşulan ağzın aynısı olduğunu, konuştukları dilin Oğuz etno-kültürel sistemi içinde yer aldığını ifade etmektedir. Anadil, Ahıska Türklerinin hangi dilleri bildikleri ve gündelik hayatta en çok hangi dili kullandıkları üzerinden ele alınmıştır. Katılımcıların ifadelerinden Ahıska Türklerinin en çok kullandıkları dilin Türkçe olduğu anlaşılmaktadır:

İngilizcemiz çok iyi olmadiğı için Türkçe konuşuyoruz. Bu sokak var ya hep Ahıskalılar var, hepsiyle hep Türkge konuşuyoruz. Annemizin kız kardeşine hala diyoruz, babamızın kız kardeşine bibi diyoruz. 25 aile var bu sitede 4 kelime Ingilizce konuşuyorsak diğer hep kendi dilimizi konuşuyoruz. Burada Ruslar da var onlarla Ruş̧a konuşuyoruz. Mesela burada bir Rus doktor vardı hep ona gideriz sigortamız olmadiğı için bizden çok az para alırdı, çok yardım ederdi. (Katılımcı 1, 57 yaşında, uçak mühendisi) 
Ahıska Türkleri İngilizce bilmedikleri için Ahıskalılar dışındaki insanlarla etkileşimlerinin sınırlı olduğu görülmektedir. Katılımcılar, sağlık sigortası için çok fazla para istendiğini, bunu karşılayamadıklarını ifade etmektedirler. Hem sağlık sigortaları olmadığından hem de İngilizce bilmediklerinden sağlık sorunları olduğunda dilini bildikleri Rus doktora gitmektedirler. Ahıska Türkleri, kültürel kimliklerinin bir parçasını oluşturan akrabalık ilişkileri ve akrabalık isimleri açısından değerlendirildiğinde ise, geleneksel akrabalık ilişkilerini korudukları gözlenmektedir. Katılımcı 1'in teyzeye hala, halaya ise bibi, dediklerini belirtmesi Yüzbey (2008: 685)'in araştırmasındaki akrabalık isimlerini doğrulamaktadır.

Evde tamamen Ahıska dilini konuşuyoruz. Çocuk bile evde İngilizce dilini konuşamaz. Eğer çocuk İngilizce dilini evde konuşursa o yarm beni de çevirir. Anlatırız ona evde Türkçe konuş dı̧̧arda arkadaşınla hangi dili konuşursan konuş. Eğer İngilizce söylerse yarn Türkçe söylemek istemez. O zaman nasıl saklarım Ahıska dilini, benim babam saklamıs vaktinde. Eğer ben Özbek dilini söyleseydim, Özbek kızını alsaydım o da Müslümandr, Ahıska ölmüştü, gitmişsti. (Katılımcı 3, 60, inşaat mühendisi)

Katılımcı 3'ün ifadeleri Ahıska Türklerinin endogamik bir grup olduklarını ortaya koymaktadır. Ahıska Türkleri etnik gruplarının dışına kız vermeyerek ve dışarıdan kız almayarak etnik kimliklerini ve kültürlerini korumayı başarsalar da Yüzbey (2008: 682)'e göre asimile olma ve sürgün korkusu Ahıska Türklerini hiçbir zaman terk etmemiştir. Katılımcı 4, kültürlerini korumak adına Müslüman bir topluluk olan Özbeklerin dilini konuşmadıklarını ve Özbeklerle evlenmediklerini vurgulamaktadır.

Evde Türkçe konusuyoruz. Ahıskalılarla, Türkiyeli Türklerle hep Türkçe konuşuruz. Ahıskalılarla konuştuğumuzda arada Ruş̧ayı, Özbekçeyi katıyoruz. Ben bir okulda çalışıyorum orda biraz İngilizce konuşuyorum. Çocuklar dı̧̧arda, okulda İngilizce konuşuyorlar çünkü diğgr çocuklar İngilizce konuşuyor ama evde Türkçe konuşuyorlar bizimle. Biz Ingilizce konuşsak onlarda hep Ingilizce konuşur. (Katılımc1 4, 63, iş̧̧i)

Katılımcıların çocukları dışarıda İngilizce konuştukları halde, evde Türkçe konuşmaktadırlar. Elde edilen bulgular, Kolukırık (2011: 184)'ın araştırma sonuçlarıyla benzerlik taşımaktadır. Ahıska Türkleri arasında İngilizcenin 
okula giden çocuklar ve gençler tarafından akıcı şekilde konuşulduğunu, çalışma yaşamındaki nüfusun ise sınırlı İngilizceleriyle günlük ihtiyaçlarını karşılamaya çalıştıklarını ifade etmiştir.

Evde kendi Türkçemizi konuşuyoruz. Tamirci olarak çallşıyorum. İlk çalıştı̆̆ım yerde İngilizce bilmediğimizden Rusça konuşuyorduk. 9 yıldor çalıştığım yerde manegermmla (yöneticimle) Ingilizce konuşuyorum ama yanımda Ahıskalılar da çalıştığ için genelde Türkçe konuşuyoruz. Ahıskalı birisini gördüğ̈̈mde Türkçe konuşuyoruz, başka dil konuşmayız. Ama o Türkçe biraz değişiktir, Ahıskalılarla konuştuğumda Ruş̧a, Özbekçe karışır yani sen anlamazsin ne konuştuğumuzu. (Katılımc1 5, 50 , işçi)

Evimizde Türkçeden başka bir dil konuşulmaz izin vermeyiz ama dtşarda ben bilemem çocuklar hangi dili konuşuyor. Ona da bir şey demiyoruz ögrensinler İngilizceyi ama Türkçeyi de ögrensinler. (Katılımcı 6, 58 , iş̧̧i)

Günlük hayatta birkaç dili konuşuyoruz. Evde isek Türkģe konuşuruz, Ahıskalılarla berabersek Türkşe konuşuoruz. Bu bütün Ahıskalılarda böyledir. Biz bir arada iken başka dil konusulmaz, bu demek değildir hiç Ruş̧a konuşmuyoruz ya da Özbekçe kelimeler yok konuşmamızda. Çalıştı̆̆ım yerde hep İngilizce konuşuyoruz zaten İngilizceyi öyle öğrendim çünkü herkes İngilizce konuşuyor. (Katılımc1 7, 48, işçi)

Yukarıdaki anlatılanlardan da anlaşılacağı üzere çalışma yaşamındaki Ahıska Türklerinin gündelik yaşamda en çok kullandıkları dil Türkçe’dir. Ayrıca Rusça ve Özbekçe de bilmekte ve ihtiyaç duyduklarında kullanmaktalar.

Bizimle konuşanlar diyorlar ki siz temiz Türkçe konuşuyorsunuz. Çalıştı̆̆ımız iş yerinde Türkçe konuşuyoruz. Aslında İngilizce konuşmamız lazım ama bizim İngilizcemiz çok yok. Evde zaten hep Türkçe konuşuyoruz, başka bir dil bilmiyoruz. Birkaç Rus komşumuz var onlarla Ruş̧a konuşyoruz. Diğer komşularımız Amerikal, onlarla az konuşuoruz Ingilizceden dolayı. (Katılımcı 9, 65, işsiz)

Ahıska Türkleri anadili muhafaza etmenin ve çocuklarına aktarmanın kültürel kimliklerini korumak açısından öneminin farkındadırlar. 


\section{Müslümanlık}

Kültürün temel yapı taşlarından birini oluşturan din, kimlik tanımlamalarında önemli yer tutmaktadır. Ahıska Türklerinin de kimliklerini Müslümanlıkla birlikte tanımladıkları görülmektedir.

Elhamdülillah Türk’üz, ama hepimiz Müslümanız. Müslümanlı̆ğ terk etmeyiz. Müslümanlığı bırakmadığımız için Rusya'da bu bale düştük. (Katılımcı 4, 63, iş̧̧i)

Katılımcı 4 ve 5 kimliklerini Müslüman Türk olarak tanımlamaktadırlar. Katılımcı 4, anavatanlarından sürülme sebeplerini Müslüman olmalarına bağlamaktadır. Katılımcı 5 ise Türkiye'de yaşayanlar tarafından Ahıska Türklerinin tanınmadığını düşünmektedir.

Biz kendimizi Müslüman Türk olarak görüyoruz. Hacca gittim, bizim hoca Türkiye'den, zannediyor ki ben de Türkiye'denim. Özbek gördüm, Özbekçe konuştum, Rusya'dan gelenlerle Rusça konuştum. Sordu bana: Sen nerelisin? Dedim Türk'üm. Türkiyenin neresinden? Dedim Türkiyénin hiçbir yerinden değilim. Nasil diyor sen Türksü̈n? Evet. Müslüman misın? Evet, Müslümanım, Müslüman olmazsam! Nasıl hacca gelirim. Dedim ki ben Ahıska Türk’üyüm. Sonra orda bir adam dedi ki hocam gerçek Türk bunlar. Türkiyédekilerin çoğu bunu bilmiyor. Biz Müslüman olduğumuzla, Türk olduğumuzla gurur duyиyoruz. Bütün dünya Müslüman olsa daha güzel olur. (Katılımcı 5, 50, işçi)

Bazı katılımcılar dinle ilgili görüşlerini evlilikle bağlantılı olarak açıklamışlardır. Sonraki kuşakların Müslüman olmayanlarla evlenmesini, kültürlerinin kaybolmasına neden olacağı için istememektedirler:

Allah'a çok şükür Müslümanız. Mesela torunumun yabancı biriyle evlenmesine sicak bakmam. Amerikalı birisiyse hiç izin vermem. Eğer ki onu Müslümanliğa çevirse, o zaman belki olur. Ya bizimki onlarn dinine geçse ne olacak! Allah çarpmasın. Zaten Hristiyan'a kız verilmez, verdin mi cehennem azabı olur o. Bizim gelinler hep Ahıskalidır. (Katılımc1 9, 65, işsiz)

İzin vermeyiz çocuklarımızın Amerikalı birisiyle evlenmesine. Atalarmızdan kalmıs kültürümüzü kaybetmeyiz. Şimdi kız Amerikalı olsa, Müslüman da olsa olmaz kültürümüz farklıdır. Bizim yanımızda ya- 
şayamaz çok zordur. Biz o yüzden dı̧̧arıya kız vermeyiz dı̧̧arıdan kız almayız. Ahıskalılar birbirleriyle evlenirler kendi kültürlerini korumak için. (Katılımcı 6, 58, iş̧̧i)

Katılımcılar, Müslüman olmayan bir kültürde çocuk yetiştirmekten ve farklı kültürlerle temasın gelecek kuşaklarda kültürel kimliklerini değişime uğratacağından kaygı duyduklarını belirtmişlerdir:

Beni dövsen de öldürsen de ben dönmem Müslümanlı̆̆ımdan ama çocuklarımız için korkuyoruz. (Katılımcı 4, 63, iş̧̧i)

Sonumuzdan razı değilim istemiyorum ki kız torunum açık saçık giyinsin. Bu kız açık gitse senin rubun (akrabalar) diyecek ki hiç mi buna öğüt ögretmemişsen. Ama gelecekten çok korkuyoruz. Bak komşularımız var Bosnalı onlar da Müslüman ama çocukları Amerikalılar gibi yaşıyorlar bizden önce gelmişler tabi. Bizde 10-20 yal daha yaşasak burada çocuklarımız onlar gibi olur. (Katılımcı 8, 50, işçi)

Katılımcı 8'in ifadelerinden geniş aile bağlarının çocukların yetiştirilmesinde de etkili olduğu görülmektedir. Aydıngün ve Aydıngün (2014: 140)'e göre Ahıska Türklerinde ailenin başarısı, ailenin adının saygınlığı gibi değerler bireysel özgürlüklerin önünde tutulmaktadır. Bireyler, özgürlüklerinin sınırlanması karşılı̆̆ında ailelerinden hem maddi hem manevi olarak büyük destek görürler. Ahıska Türkleri kültürlerini korumak için Müslüman da olsa dışarıya kız vermeyi ya da dışarıdan kız almayı tercih etmemektedirler.

\section{Sonuç}

Ahıska Türklerinin göç sürecine ve kimliklerine odaklanılan bu çalışmada; Ahıska Türklerinin göç türünün zorunlu ve zincirleme göç olduğu saptanmıştır. Zorunlu göçün nedeni, Ahıska Türklerinin Krasnodar'da yaşadıkları sorunlar ve onlara uygulanan ayrımcılıktır. Yaşadıkları bu olumsuzlukları Türk ve Müslüman olmalarına bağlamaktadırlar. Göç etmeden önce yaşadıkları sorunlara bakıldığında en önemli sorunlar olarak; eğitim hakkının verilmemesi, yurt dışında okuyanların bile döndüklerinde iş bulamamaları, pasaport ve kimlikleri olmadığı için gayrimenkul aldıklarında kendi adlarına kaydettirememeleri, güvenlik kaygısı yaşamaları ortaya çıkmıştır. Bunun yanı sıra Ahıska Türkleri, anavatan olarak gördükleri Türkiye’ye göç etmeyi tercih ettiklerini ama o sırada Türkiye'den destek gelmediği için Amerikàya göç etmek zorunda kaldıklarını ifade etmişlerdir. Hutchinson ve Smith 
(1996) etnik kimliği; ortak ecdat mitine, paylaşılan tarihi hatıralara, ortak kültüre, ortak bir anavatana ve ortak dayanışmaya dayanan belirli bir insan topluluğuyla ilişkilendirir. Bu anlamda Ahıska Türklerinin duyumsadıkları etnik kimliğin Türk olduğu tespit edilmiştir. Ahıska Türklerinin Amerika’ya göç ettikten sonra yaşadıkları sorunlar ise İngilizceyi iyi bilmemeleriyle ilişkilidir. Bu nedenle özellikle göç eden ilk kuşak, iyi İngilizce bilmemesinden ötürü pasaport almak için girdikleri sınavlarda başarılı olamamış ve Amerika göçmen alımını durdurduğu için geride bıraktıkları akrabalarını ziyaret edememekte, duydukları özlemi her firsatta dile getirmektedirler.

Ahıska Türkleri, tarihleri boyunca baskı, zulüm ve sürgün yaşadıkları için ontolojik güvensizlik duymakta ve bu güvensizliği bastırmak için geniş aile bağlarına ve akrabalık ilişkilerine önem vermektedirler. Akrabalık ilişkilerine verilen önem ve yaşadıkları güvensizlik, zincirleme göçü tercih etmelerine neden olmuştur. Amerika’ya daha önce göç eden akrabalarından edindikleri bilgiler doğrultusunda akrabalarının yönlendirmeleriyle Amerika’ya göç etmişlerdir.

Ahıska Türklerinin aile yapısının geleneksel geniş aile olduğu görülmektedir. Geleneksel geniş aile, aile başkanı ve karısıyla evli oğulları, gelinleri veya bir evli oğul ve diğer bekâr çocukları ya da tek bir evli oğul, gelin ve torunlarının birlikte oturdukları (Timur 1972) bir aile tipidir. Geleneksel geniş aile, dayanışma ve toplumsal güvenlik kurumudur (Eyce 1994). Ahıska Türklerinin, geleneksel geniş aile şeklinde yaşamaları ve dışarıdan evlenmeyi tercih etmemeleri, dışa kapalı bir topluluk olduklarını ve bu durumun hem göç ettikleri topluma daha hızlı uyum sağlamada, hem de kültürel kimliklerinin korunması ve aktarımında işlevsel olduğu belirtilebilir. Yüzbey (2008) de Ahıska Türklerinde bir içe kapanma olduğunu ifade etmektedir.

Ahıska kimliğini oluşturan öğeler; Türklük, Türkçe ve Müslümanlık olarak ortaya çımıştır. Türklük ve Müslümanlık kimliklerinin değişmez, vazgeçilmez öğelerini oluşturmaktadır. Yaşadıkları baskıya rağmen kimliklerinden vazgeçmediklerini vurgulamışlardır. Dil ise, Amerika’ya göç eden ilk kuşak açısından olmasa da daha sonraki kuşaklar açısından değişime açık bir kültürel kimlik öğesidir. İlk kuşak gündelik hayatlarında Türkçe’yi kullansa da gençler İngilizceyi iyi bilmektedir. Bu durum ilk kuşakta, ileride kültürel kimliklerini kaybedecekleri ve asimile olacakları gibi kaygılara yol açmaktadır. Bunun yanı sıra Ahıska Türkleri arasında çok dilliliğin yaygın olduğu 
gözlenmiştir. Daha önce Özbekistan'a, oradan da Rusya'ya göç ettirilmeleri çok dilliliği açıklamaktadır. Kendi aralarında konuşurken arasına Özbekçe ve Rusça kelimelerin serpiştirildiği, dışarıdan birisinin anlamasının zor olduğu bir Türkçe kullanmaktadırlar. Türk birisiyle konuşurken ise daha yalın bir Türkçe kullanmaya özen göstermektedirler.

Son olarak kendilerini tanımlarken Ahıska Türkü kavramının kullanılmasından hoşnut olmadıkları, kendilerini Türk ya da Osmanlı Türk’ü olarak tanımladıkları dikkat çekmektedir. Ahıska, onlar için sadece coğrafi bir tanımlamadan ibarettir. Bu çalışmada da Ahıska kavramı coğrafi bir adlandırmadan öte bir anlam taşımamakta, grubun kendilerini tanımlarken kullandıkları kimlik tanımları kabul edilmektedir. Ahıska Türkleri, yurtlarından çok uzakta yaşıyor olsalar da dinlerini, kültürlerini ve kimliklerini korumayı başarmış bir topluluktur.

\section{Kaynaklar}

Ağır, Osman ve Murat Sezik (2015). "Suriye'den Türkiye’ye Yaşanan Göç Dalgasından Kaynaklanan Güvenlik Sorunları”. Birey ve Toplum 5 (9): 95123.

Aka, Assiye (2010). "Kimliğe Teorik Yaklaşımlar”. C.Ü. Sosyal Bilimler Dergisi 34 (1): 17-24.

Aliyeva, Minara (2015). “Ahıskalı Türklerde Dilin Önemi ve Yazı Dili Sorunu”. Uluslararası Ahıska Hukuki ve Sosyal Sorunlar Sempozyumu. Ankara: Astana Yay. 435-443.

Alver, Köksal (2006). "Edebiyat ve Kimlik". Bilgi Sosyal Bilimler Dergisi 13 (2): 32-42.

Aslan, Ahmet Ali (2015). "Ahıska Türklerinin Amerika’ya Göçü: Amerika’nın Uyguladığı Bir Sosyal Mühendislik Projesi”. Uluslararası Ahıska Hukuki ve Sosyal Sorunlar Sempozyumu. Ankara: Astana Yay. 58-76

Aydıngül, Ayşegül (2013). "Ahıska Türklerinin Dünü, Bugünü ve Yarını". Yeni Türkiye Türk Dünyası Özel Sayısı II: 2665-2674.

Aydıngün, Ayşegül ve İsmail Aydıngün (2014). Ahıska Türkleri Ulusötesi Bir Topluluk Ulusötesi Aileler. Ankara: Ahmet Yesevi Üniversitesi MHB Yay.

Aydıngün, Ayşegül, Çiğdem Balım Harding, Matthew Hoover, Igor Kuznetsov \& Steve Swerdlow (2006). Meskhetian Turks-An Introduction to Their History, Culture and Resettlement Experiences. Washington: Center for Applied Linguistics. 
Barth, Frederick (2001). Etnik Gruplar ve Sınırları: Kültürel Farklılı̆̆ın Toplumsal Organizasyonu. Çev. A. Kaya ve S. Gürkan. İstanbul: Bağlam Yay.

Bilgin, Nuri (2007). Kimlik İnşası. İzmir: Aşina Yay.

Buntürk, Seyfeddin (2015). "Sovyet Belgeleriyle 1944 Ahıska Sürgünü”. Uluslararası Ahıska Hukuki ve Sosyal Sorunlar Sempozyumu. Ankara: Astana Yay. 87-99.

Demiray, Erdinç (2012). “Anavatanlarından Sekiz Ülkeye Dağıtılmış Bir Halk: Ahıska Türleri”. Turkish Studies 7 (3): 877-885.

Eyce, Berrin (1994). Konya'da Küçük Sanayide Çalı̧an Ailelerde Kadının Sosyal Kontrol Gücü. Doktora Tezi. Ankara: Hacettepe Üniversitesi.

Geertz, Clifford (1963). "The Integrative Revolution: Primordial Sentiments and Civil Politics In The New States". The Interpretation of Cultures. New York: Basic Books. 105-157.

Hasanoğlu, İbrahim (2015). “Ahıska Türklerinin Geri Dönüş Sorunu ve Gürcistan’ın Yükümlülükleri”. $O A K A 10$ (20): 75-105.

Hutchinson, John ve Anthony Smith (1996). Ethnicity. Oxford: Oxford University Press.

Kahraman Özözen, Selver ve Aydın İbrahimov (2013). "Kafkaslardan Sürgün Bir Toplumun Bitmeyen Göçü: Çanakkale'de Ahıska Türkleri”. Ege Coğrafya Dergisi 22 (2): 77-90.

Karaduman, Sibel (2010). "Modernizimden Postmodernizme Kimliğin Yapısal Dönüşümü”. Journal of Yasar University 17 (5): 2886-2899.

Kolukırık, Suat (2011). "Sürgün, Toplumsal Hafıza ve Kültürel Göç: ABD’deki Ahıska Türkleri Üzerine Bir Araştırma”. Bilig - Türk Dünyası Sosyal Bilimler Dergisi 59: 167-190.

Kurt, Selim (2015). "Ahıska Türkleri ve Ahıska Yurdunun Türkiye İçin Önemi”. Uluslararası Ahısa Hukuki ve Sosyal Sorunlar Sempozyumu. Ankara: Astana Yay. 193-212.

Kurt, Halil ve Mehmet Ali Açıkgöz (2017). "ABD’de Yaşayan Ahıska Türkleri”. MUTAD IV (I): 107-127.

Kümbetoğlu, Belkıs (2005). Sosyolojide ve Antropolojide Niteliksel Yöntem ve Araştırma. İstanbul: Bağlam Yay.

Önder, Ali Tayyar (2002). Türkiyénin Etnik Yapısı, Halkımızın Kökenleri ve Gerçekler. İstanbul: Pozitif Yay.

Özer, İnan (2004). Kentleşme, Kentlileşme ve Kentsel Değişme. Bursa: Ekim Kitabevi. Patton, Michael Q. (2002). Qualitative Research and Evaluation Methods. Thousands Oaks, Sage Publication.

Schonpflug, Ute (2009). Culturel Transmission. Cambridge: Cambridge University Press.

Shills, Edward (1957). "Primordial, Personal, Sacred and Civil Ties”. British Journal 
of Sociology 8 (2): 130-45.

Sözen, Edibe (1998). "Modernite ve Kültürel Kimlik”. İstanbul Üniversitesi Sosyoloji Konferansları Dergisi 25 (1): 153-160.

Timur, Serim (1972). Türkiye'de Aile Yapısı. Ankara: Hacettepe Üniversitesi Yay.

Yıldırım, Ali ve Hasan Şimşek (2005). Sosyal Bilimlerde Nitel Araştırma Yöntemleri. Ankara: Seçkin Yay.

Yıldız, Recep ve Sakine Demir (2015). "Mili Kimliğin Oluşumunda Zihniyet”. Dumlupınar Üniversitesi Sosyal Bilimler Dergisi 8: 1-25.

Yılmaz, Abdurrahman (2014). "Uluslararası Göç: Çeşitleri, Nedenleri ve Etkileri”. Turkish Studies 9 (2): 1685-1704.

Yılmaz, Ali ve Rüstem Mustafa (2014). “1992 Sonrası Türkiye’ye Göç Eden Ahıska Türklerinin Göç, İskân ve Uyum Sorunlarına İlişkin Bir Araştırma, Bursa Örneği”. Studies of the Ottoman Domain 4 (6): 1-19.

Yüzbey, İrade (2008). "Ahıskalı Türkler ve Kültürleri” Turkish Studies 3 (7): 679695. 


\title{
The Construction of Ahıska Identity in Migration Process: Ahıska Turks who Migrated to The United States ${ }^{*}$
}

\author{
Tuğça Poyraz** \\ Abdurrahim Güler ${ }^{* * *}$
}

\begin{abstract}
In this study, elements constituting identities of Ahiska Turks who migrated to Jacksonville, Florida, between 2005 and 2007 was tackled in terms of migration process. The objective of this study is to present the reasons why the Ahiska Turks migrated to United States, the problems they faced before migration, and the effects of migration process on their identities. Data are obtained during January-March, 2016 from Ahiska Turks who live in Jacksonville, Florida. In-depth interviews with 9 Ahiska Turks and the participant observation was conducted in spaces where they spend their daily lives by forming an interaction in order to comprehend their social realities from their own point of view. The study revealed that discrimination toward Ahiska Turks before their migration to the United States was the most important problem they had. Further, It was observed that the Ahiska Turks involuntarily migrated to the United States with their families and they preserved the fundamental elements of their identities after their migration. Moreover, the basic elements determining the identity of Ahiska Turks are found to be Turkishness, Turkish, and Islam.
\end{abstract}

Keywords

Ahiska Turks, migration, forced migration, chain migration, cultural identity, ethnic identity, religious identity.

\footnotetext{
* Date of Arrival: 03 February 2018 - Date of Acceptance: 12 July 2018

You can refer to this article as follows:

Poyraz, Tuğça ve Abdurrahim Güler (2019). "Ahıska Kimliğinin Göç Sürecinde İnşası: Amerika’ya

Göç Eden Ahıska Türkleri”. bilig - Journal of Social Sciences of the Turkic World 91: 187-216.

"* Assoc. Prof. Dr., Hacettepe University, Faculty of Letters, Department of Sociology - Ankara/Turkey ORCID ID: https://orcid.org/0000-0003-3717-4728

tpoyraz@hacettepe.edu.tr

${ }^{* * *}$ Dr. Lecturer, Agrı İbrahim Çeçen Üniversitesi, Faculty of Sciences and Letters, Department of Sociology

- Agri/Turkey

ORCID ID: https://orcid.org/0000-0002-0317-8221

aguler@agri.edu.tr
} 


\title{
Идентичность месхетинцев в процессе миграции в США*
}

\author{
Тугча Пойраз \\ Абдуррахим Гюлер ${ }^{*+*}$
}

\begin{abstract}
Аннотация
В этом исследовании рассмотрены с точки зрения процесса миграции элементы, составляющие идентичность месхетинских турок, которые мигрировали в Джексонвилл, штат Флорида, между 2005 и 2007 годами. Цель данного исследования - представить причины, по которым турки-месхетинцы мигрировали в Соединенные Штаты, проблемы, с которыми они сталкивались до миграции, и влияние миграционного процесса на их идентичность. Использованы данные, полученные в январе-марте 2016 года от турок-месхетинцев, которые живут в Джексонвилле, штат Флорида. Обстоятельные интервью с девятью месхетинцами и наблюдения за ними проводились в местах, где они проводят свою повседневную жизнь, было обеспечено взаимодействие, которое позволило характеризовать социальные реалии месхетинцев с их собственной точки зрения. Исследование показало, что дискриминация в отношении этой группы до их переселения в Соединенные Штаты была самой важной проблемой, с которой они столкнулись. Кроме того, было отмечено, что туркимесхетинцы вынужденно мигрировали в Соединенные Штаты вместе со своими семьями, и они сохранили основополагающие элементов своей самобытности после миграции, среди которых основными можно считатьпринадлежностьктюркскимнародам, тюркский языки ислам.

\section{Ключевые слова}

турки-месхетинцы, миграция, вынужденная миграция, цепная миграция, культурная идентичность, этническая идентичность, религиозная идентичность.
\end{abstract}

\footnotetext{
* Поступило в редакцию: 03 февраля 2018 г. - Принято в номер: 12 июля 2018 г.

Ссылка на статью:

Poyraz, Tuğça ve Abdurrahim Güler (2019). “Ahıska Kimliğinin Göç Sürecinde İnşası: Amerika’ya Göç Eden Ahıska Türkleri”. bilig - Журнал Гуманитарных Наук Тюркского Мира 91: 187-216.

** Доц., д-р, Университет Хаджеттепе, Филологический факультет, отделение социологии Анкара / Турция

ORCID ID: https://orcid.org/0000-0003-3717-4728

tpoyraz@hacettepe.edu.tr

*** Д-р, преподаватель, Университет имени Ибрагима Чечена, г. Агры, Факультет искусств и наук, кафедра социологии - Агры / Турция

ORCID ID: https://orcid.org/0000-0002-0317-8221

aguler@agri.edu.tr
} 